\title{
研究会インタビュー ソサイエティ人図鑑 No.25
}

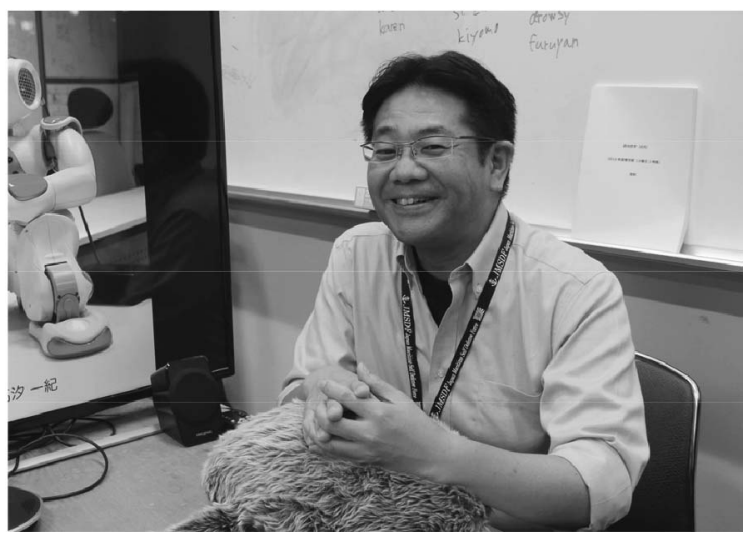

\section{高汐一紀さん}

所属：慶應義塾大学環境情報学部教授

分野：クラウドネットワークロボティクス, ソーシャルロボ テイクス，ヒューマンロボットインタラクション， ユ ビキタスコンピューティング

インタビュー：西尾直樹（聴き綴り本舗 nishio.info@gmail.com), 編集 : 佃芳史春

\section{— 研究について御紹介下さい.}

大きく二つあります。一つはクラウドネット ワークロボティクス。ロボットと IoT, 更には 様々な情報サービスとを接続させて大規模なシ ステムとして運用する研究です，例えば，ロボッ トが自動運転車を呼んで, 現在地と行き先を自 動運転車に伝達, 移動中はドローンが常にウォッ チして，家族に地図上のどこを移動しているか お知らせする，全部がつながって，うまく情報交 換をする仕組みです．この仕組みが進化すると， 複数のロボットや情報が接続されるので, 病院 の受付でヒューマノイドロボットに話しかける だけで，自動的に予約状況が分かって，診察室の 機械が患者の状況に合わせて自動的に動き出す, みたいな世界が実現します。なかでも，そのフロ ントエンド，エッジ端末となるロボットと人との インタラクションに注目しています。現在のロ ボットは一対一でのコミュニケーションしか想 定していません，誰かが会話に入ると，コンテ クストがぐちゃぐちゃになる。そこを改善する研 究です. OSで言えばコンテクストスイッチング, つまりプロセススケジューラに相当する部分.

もう一つはソーシャルロボティクス.ロボット との社会的な関わり方，ロボットそのものにど
う社会性をもたせるか. 世界的にヒトと共生・協 働できるロボットの研究が進んでいますが，日 本は次はどこを目指すのかを考えたときに、「ロ ボットの共進化」というキーワードが出てきま す。社会性を帯びて，人間の成長にあわせて，口 ボットも成長する。現時点で，ロボットは没個 性です，買ってきたら，その形や色，内面，性格 は変わらない，性格が変わっていくロボットが 出てくれば,「ロボットを育てる」という感覚を ヒトがもつかもしれません.アルゴリズムを工 夫すれば，ふてくされたり，つれなかったりも するロボットになるかもしれません，対人情動 や場所に対する情動の変化. これらはヒトとの インタラクションの過程で育っていくはずなの で，ロボットに発達心理学での知見を実装して， 研究しています。よく遊んだロボットは，よく 反応を返してくれたり。今市場にあるロボット も，1か月くらいは学習してくれます。それを長 くする.「あ，これ，育て方間違えたな」と思う くらいの長いスパンに。そうすれば愛着が湧い てきます。例えば，お隣さんと同時期に同じロ ボットを導入したけど，うちのロボットはよそ と違う，と思うのはどのタイミングなのか. ヒ トが成長し，社会が変わっていけば，当然，ロ ボットも変わっていく，外観も中身も，アップ 
デートできるロボットを作りたいです.

世の流れとしては，ロボットと AIをくつつけ， 知的存在にしょうとしていますよね. その次は ロボットメニューロサイエンス，ロボットメバ イオサイエンスの研究が進むでしょう。ただ単 純に知能をもたせるのではなくて，ロボットコ ミュニティの中で知能を共有させることで, 全 体知が生まれます。全体知があれば，ロボット がもっとヒトとうまく付き合っていけるのでは と期待しています.

\section{一今, 一番力を入れていることを教えて下さい.}

間合いのインタラクションです. ヒト同士の コミュニケーションを，ロボットにどうエンハ ンスさせるか. 今のロボットはまだ色んなこと に気づいてくれない. ヒトのメンタルまで含め た自分の周りの状況をうまく理解できないんで す. 状況を読み取って話題を振るには, 一人称 視点のロボットが必要です。複数人の話を区別 し，その上で，今，話しかけていいのか. 自分 のターン，間合いを判断する，現在の技術では， ヒトの表情や声の抑揚の変化をセンサで感知し て,「あ，これはまずかったのかな」と，話し方を 変えたり，話題を変えたりすることができます。 ですが，その後が相当難しくて，感知したとし てもロボットが急に話しかけてしまうんですね. 私たち人間はパーソナルスペースをもっていて, いきなり話しかけられたり，グイグイ迫られた りすると，ビックリしてしまいます。日常生活 の中に間合いの取れないロボットを取り入れる と，ヒトはすぐに飽きてしまうでしょう。今は 何となく我々がロボットに気を遣っている状態 です。掃除ロボットの邪魔にならないように家 具の位置を変えたり，コミュニケーションロボッ トに伝わるように分かりやすく話を合わせたり. ロボット自身が間合いのインタラクションを実 装して，もっとソーシャルになれば，ヒトとロ ボットが身近に暮らす世界がより早く実現する
のではと思います。

私が所属する SFCは，Fabキャンパスを謳っ ていて，レーザーカッター， CNC，3D プリンタ など，学生が発想したアイデアを形にするため の環境が揃っています。また，未来構想キャン プというのもあって, 高校生がインターンとし て研究活動に参加する機会もあります。そうし た学生らと日々, ロボットとは何か, という本 質的な議論をしています。その中では，そもそ もヒトがどういうインタラクションをしている のか，動画を撮って一緒に見る機会があるんで すね. コミュニケーションサイエンスの分野で すけど,「あー」「えー」などいわゆるフィラー を入れた方が，会話がスムーズにいく，じゃあ， それを踏まえて，ロボットに実装するとどうな るか. 会話のデザイン, 文脈そのものを作り出 すことに関しては私は素人なので，自然言語処 理の研究者や企業と連携もしています. シミュ レーションではうまくいくことも，身体性を備 えたロボットで喋らせたとき, やっぱり反応が 違うんです。受付ロボットにうまく喋らせるに はどうすればいいか. 間合いの作り方，フィラー やモーションの入れ方. 研究を重ねています.

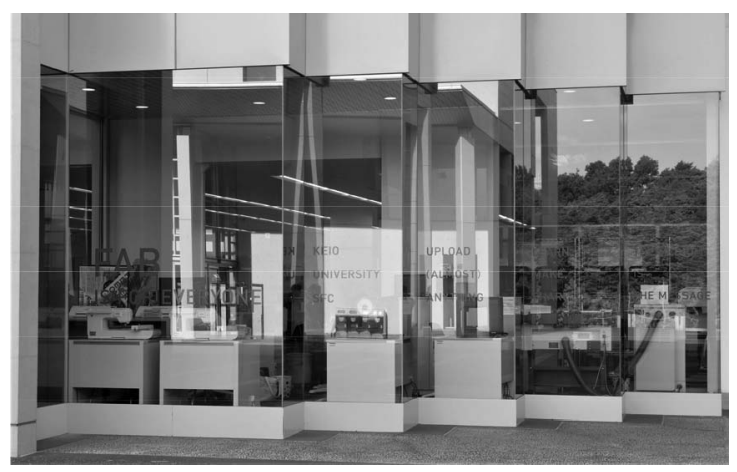

一研究会についてお聞かせ下さい.

クラウドネットワークロボット研究会 $(\mathrm{CNR})$ ではこの 6 月から委員長をしています。CNRは 元々ネットワークにつなげたロボットを扱って いて，どちらかというとシステム，インフラ寄 
りでした。私が興味を持っているのは，それを 使って，ロボット同士がどうコミュニケーショ ンをとるか. 今, CNRでよく発表されているの は，ヒトとロボットがどうインタラクティブに なるかです。よりヒトのメンタルに踏み込んだ ロボットの研究が盛んになっています.

この研究会の特徽は, 企業関係者とアカデミ アが半々くらい.うまくまとまれば産学連携の インフラになりえます。研究会が扱う範囲も広 いですね。単純にシミュレーションやエージェ ントソフトとのやりとり, 自然言語処理だけの 研究には止まりません，ロボットに身体性をも たせたときに何が起きるかを議論しているのも 特徵的ですね. 実証実験のプラットフォームや, フィージビリティスタディで得られた知見の共 有も進んでいます。新しいつながりもたくさん できています。ロボット系の研究者とより墚い つながりを作るのが次のステップで，ロボット 学会側の研究会と共催で研究発表会を年に一度 開いたりして，交流を促しています。ロボット， 身体性，情報の三角形ができると，未来がより 明るくなりそうなので，この一年が研究会とし ても頑張りどころですね.

\section{一研究のきっかけを教えて下さい.}

ロボットに興味をもったのは，中学生のとき に見た映画スター・ウォーズのエピソード 5 「帝 国の逆襲」のラストシーンです. 敵に腕を切り 落とされた主人公が義手をつけるんですが，カ バーがパカっと開いて，中に何本もシャフトが あって。指先を針で刺激すると，中のシャフトが カチャカチャ動いて, 義手の指がピクピク動く. ものすごく衝撃を受けました。それで，ロボッ トをやりたい! となって, 大学では理工学部を 選択しました，専攻を選ぶタイミングが，ちょ うどパソコンが世に出始めた頃. 大学にワーク ステーションが並び始めた時期です．ある授業 をきっかけにプログラミングにはまって，ロボッ
トのことはすっかり忘れて, OS やプログラミン グの計算モデルをやる研究室に入りました。

修士課程 2 年のときに, 恩師の所眞理雄先生

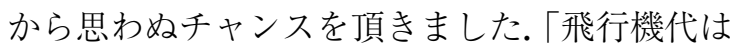
出すから, 滞在費は自分で.アメリカ（カーネ ギー・メロン大学の德田英幸先生の研究室）に 行ってこい」と. 勢いで $2 \sim 3$ か月飛び込んで みると，気づいたことがあって，それは，海外 で勝負している日本人がいるということ. 徳田 先生がそうなんですけど，教授のポジションを 取ってきて，学生と新しい論文をどんどん出し て，打金も引っ張ってくる。一緒に研究に加わ ることで，アカデミアでのロールモデルを見つ けました，それで，奨学金をもらいながら，博 士課程に．博論は分散実時間システムを効率的 に記述するためのオブジェクト指向プログラミ ング言語です，就職してからも，情報工学系で した、流れで, ユビキタスコンピューティングの ガジェット, センサネットワーク, 大規模分散シ ステムのデザインを 10 年ほど研究しました。ま た徳田先生から御縁を頂いて， $\mathrm{SFC}$ 。 あると き, $\mathrm{SFC}$ の村井純先生から携帯に電話がかかっ てきて,「何ですか?」「サバティカルの枠が一個 余ってるんだけど，行かない?」と.10秒くら い考えて，「行けるんだったら，行きます」と勢 いで答えました．留学先はドイツのミュンヘン 工科大学. 受け入れ先の Gordon Cheng 先生か らは「ロボット用の人工皮虐，センサ用のソフ トゥェアを作ってほしい」というオーダーがあ りました，籍を置かせてもらったのは，認知シ ステム研究所.でも実際に行ってみると, ロボッ トの研究でした、ロボットとヒトがどうインタ ラクションするかを皆が真剣に議論しているん です，そんな環境で 1 年間，自分のやりたいこ とをずっと考えていて，ある日，中学生のとき のあのワンシーンが蘇ったんです.「ああ, 自分 はロボットをやりたかったんだな」と。それで， 思い切って，やりたいことを大きくシフトさせ 
ました。帰国後はそれまでの専門とは違う今の 研究室を立ち上げました。今年で 4 年目になり ます。制御工学をちゃんとやってきたわけでは ありません，どこで勝負できるか. それで，ヒ トとロボット，ロボット同士，ロボットたちと 情報システムとのつながりに着目したんです.

\section{— 今後の展望についてお聞かせ下さい.}

現在の研究のアウトプットを積極的に社会実 装することで，この新しい研究分野を軌道に乗 せることでしょうか. ロボットとヒトを分けて 研究する最後の世代に自分たちはいるなと意識 しています。今は「ロボットはロボット」「ヒト はヒト」と別々の存在ですよね. それが，例え ば，身体拡張，オーグメンテッド・ヒューマンの ように，融合していく，分かりやすいのは義手 義足ですね. 既に，頭の中に埋め达まれた電極 や人工臓器など, インプランタブルな機械が医 療現場で使われています。コンピュータシステ ムとヒトの身体が一緒になって生きている状態 です。もともと人間がもっていない認知システ ムや感情表現器官を人工的に身につけていくこ とは技術的には可能なわけです。ロボット，計 算機, ヒトが融合する世界です，極小なサイズ のロボットが身体の中を動き回る，というのは 絵空事ではないんです，正にシンギュラリティ. そうなると，ロボットとヒトとを一緒のものと して捉えて，議論するようになるでしょう。昔 でいう，サイボーグです。ロボットとヒトをど こで線引くか. ヒトの寿命はどうなるのか. ヒ 卜はどこまで生きなきゃいけないのか. 哲学的, 究極の問いに私たちは直面するでしょう。ロボッ トがいわゆる人格や感情を備えてソーシャルな 存在になり，ヒトとの垣根が限りなくなくなっ てきたとき，それをヒトは「ヒト」と認識する のでしょうか. 機械と生命構造の区別ができな くなるかもしれません。怖いけれど，ちょっと 見てみたいですよね (笑).日頃からこんなこと
を何となく思い描いているので，ただロボット の反応やアクチュエーションの精度を上げる研 究よりも，互換性のある分野の議論と研究をし ていかなくてはと思います。義手の精度だけ上 がっていっても，身体の反応速度が噛み合わな いと実用的になりませんから。

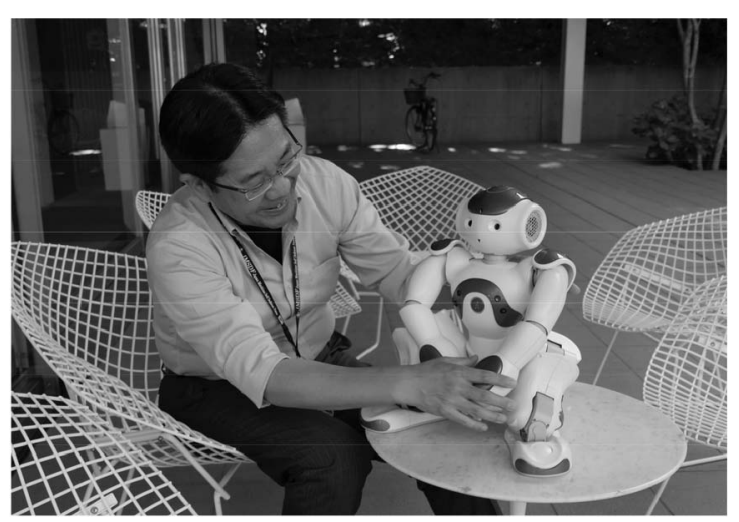

一 最後に趣味についてお聞かせ下さい.

いろいろあるのですが，最近は料理です，食 ベることもそうですが，作ることも大好き．ゼ ミで鍋会や BBQ をやったりするので，誕生日 プレゼントに鍋を贈られたこともあります。包 丁やナイフを研ぐときや，オーブンの前でケー キが焼き上がるのをじっと待つ時間は楽しいで すね.レシピを見ながら料理をしていくのです が，やはり勢いというのはあって，その場その 場で色々とアレンジします。 日本と違ってドイ ツでは誕生日ケーキは自分で焼いて，皆に配り ます。なので，子供の誕生日のときは先生やク ラスメイト分のケーキを一緒に焼いたりしまし た. 研究でなかなか良いアイデアが出ないとき もありますが，そうしたときに，頭を真っ白に できる料理の時間はとても貴重ですね.

あと昔から船が好きです。客船も貨物船とか も。こういう構造物が好きなんですね. ぼーっと 見ているのも乗るのも好きです．年をとったら陸 の資産を全部売っぱらって，船の上で生活をした いというのが，もう一つの昔からの夢です (笑). 